\title{
An $\alpha_{2}$-Macroglobulin Receptor-dependent Mechanism for the Plasma Clearance of Transforming Growth Factor- $\beta 1$ in Mice
}

\author{
Jonathan LaMarre, * M. Anthony Hayes," Gordon K. Wollenberg," Isa Hussaini," Scott W. Hall, ${ }^{*}$ and Steven L. Gonias \\ *Department of Pathology, University of Guelph, Guelph, Ontario, Canada, NIG 2WI; and the ${ }^{\ddagger}$ Departments of Pathology \\ and Biochemistry, University of Virginia Health Sciences Center, Charlottesville, Virginia, 22908
}

\begin{abstract}
Radioiodinated transforming growth factor- $\beta 1$ (TGF- $\beta 1$ ) bound to the plasma proteinase inhibitor, $\alpha_{2}$-macroglobulin $\left(\alpha_{2} M\right)$, as determined by chromatography on Superose-6 and native polyacrylamide gel electrophoresis. When $\alpha_{2} M$ conformational change was induced with methylamine, ${ }^{125}$ I-TGF- $\beta 1$ binding significantly increased. Intravenously injected ${ }^{125} \mathrm{I}$ TGF- $\beta 1$ cleared from the circulation of mice rapidly at first; however, intravascular radioactivity stabilized near $20 \%$ of the initial level. At necropsy, radioactivity was recovered predominantly in the liver (65\%); however, the density of radioactivity (disintegrations per minute/g organ wt) was highest in the lungs. Markedly different results were obtained with purified ${ }^{125}$ I-TGF- $\beta 1-\alpha_{2} M$-methylamine complex. Clearance of the complex occurred as a first-order process with a $t_{1 / 2}$ of $4 \mathrm{~min}$. Greater than $90 \%$ of the radioactivity was recovered in the liver. The clearance and distribution of ${ }^{125}$ I-TGF- $\beta 1-\alpha_{2} M$-methylamine were equivalent to those observed with ${ }^{125} \mathrm{I}-\alpha_{2} \mathrm{M}$-methylamine and ${ }^{125} \mathrm{I}-\alpha_{2} M-t r y p s i n$. The latter two radioligands clear via specific $\alpha_{2} M$ receptors in the liver. Large molar excesses of $\alpha_{2} M$-trypsin or $\alpha_{2} M$-methylamine competed with ${ }^{125}$ I-TGF-

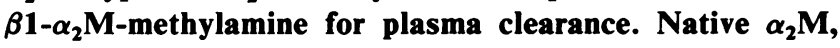
which does not bind to the $\alpha_{2} M$ receptor, did not compete. The receptor binding domain of $\alpha_{2} M$-methylamine was blocked by chemical modification or enzyme treatment. The resulting $\alpha_{2} M$ preparations still bound ${ }^{125}$ I-TGF- $\beta 1$; however, the complexes did not clear when injected intravenously in mice. The studies presented here demonstrate that $\alpha_{2} M$ can mediate the plasma clearance of a growth factor via the $\alpha_{2} M$ receptor system. We propose that $\alpha_{2} M$, the $\alpha_{2} M$ receptor, and proteinases may function as a concerted system to regulate TGF- $\beta 1$ activity and the activity of related factors in vivo. (J. Clin. Invest. 1991. 87:39-44.) Key words: growth factor • proteinase - receptor • hepatocyte $\bullet$ liver
\end{abstract}

\section{Introduction}

Transforming growth factor- $\beta 1$ (TGF- $\beta 1)^{1}$ is a $25-\mathrm{kD}$ disulfide linked homodimer (1). The active form of TGF- $\beta 1$ is a multi-

Address reprint requests to Dr. S. L. Gonias, University of Virginia Health Sciences Center, Departments of Pathology and Biochemistry, Box 214, Charlottesville, VA 22908.

Received for publication 24 April 1990 and in revised form $23 \mathrm{Au}$ gust 1990.

1. Abbreviations used in this paper: $\alpha_{2} \mathbf{M}, \alpha_{2}$-macroglobulin; $\alpha_{2} \mathbf{M}-\mathrm{M}_{\mathrm{Pt}}$, $\alpha_{2} \mathrm{M}$-methylamine treated with cis-DPP; cis-DPP, cis-dichlorodiammineplatinum (II); PNPGB, p-nitrophenyl p'-guanidinobenzoate $\mathrm{HCl}$; TGF- $\beta 1$, transforming growth factor- $\beta 1$.

J. Clin. Invest.

(c) The American Society for Clinical Investigation, Inc.

$0021-9738 / 91 / 01 / 0039 / 06 \$ 2.00$

Volume 87, January 1991, 39-44 functional regulator of cell growth demonstrating both proliferative and antiproliferative activities (2). TGF- $\beta 1$ modulates the immune response, regulates cellular secretion of extracellular matrix proteins, and affects cellular production of proteinases and proteinase inhibitors (2). TGF- $\beta 1$ activity results from interaction with specific cell surface receptors, the most important of which is probably a $53-\mathrm{kD}$ glycoprotein $(3,4)$. Since numerous normal and neoplastic cells secrete TGF- $\beta 1$ and express the TGF- $\beta$ receptor $(2,5)$, it is not clear whether physiologic mechanisms exist to direct TGF- $\beta 1$ to specific target cells.

TGF- $\beta 1$ is secreted as an inactive high molecular weight precursor with an $\mathrm{NH}_{2}$-terminal proregion (5-7). The activity of TGF- $\beta 1$ may be regulated in part by molecules that influence the rate of precursor activation. Plasmin and cathepsin-D both react with the TGF- $\beta 1$ precursor yielding active $25-\mathrm{kD}$ dimer (7). The dimers then bind to cell surface receptors or to certain soluble proteins including betaglycan (8), fibronectin (9) and $\alpha_{2}$-macroglobulin $\left(\alpha_{2} M\right)(10-12)$. These TGF- $\beta 1$ carrier molecules may transfer TGF- $\beta 1$ from one tissue to another or direct the activity to a specific cell type. In the plasma, essentially all of the TGF- $\beta 1$ is associated with $\alpha_{2} \mathrm{M}$ (10).

$\alpha_{2} \mathrm{M}$ is a $718-\mathrm{kD}$ plasma glycoprotein that inhibits numerous proteinases from all four major classes (13). Reaction of $\alpha_{2} \mathrm{M}$ with proteinase causes a major conformational change in the inhibitor (14). As a result, the proteinase is trapped and a nondissociable complex is formed. Primary amines such as methylamine react with $\alpha_{2} \mathrm{M}$ thiol ester bonds causing a conformational change similar to that induced by proteinase (14). In either reaction (proteinase or amine), the change in $\alpha_{\mathbf{2}} \mathbf{M}$ structure generates a site that binds to specific cell surface receptors on hepatocytes, macrophages, and fibroblasts (15). The native form of $\alpha_{2} \mathrm{M}$ is not recognized by the $\alpha_{2} \mathrm{M}$ receptor.

$\alpha_{2} M$ receptors have been studied extensively using in vivo model systems (15-18). In mice, receptor binding and endocytosis cause the rapid plasma clearance of $\alpha_{2} \mathrm{M}$-proteinase complexes and $\alpha_{2} \mathrm{M}$-methylamine $\left(t_{1 / 2} 3-5 \mathrm{~min}\right)$. The major organ responsible for $\alpha_{2} \mathrm{M}$-proteinase clearance is the liver (15); the primary cell type is the hepatocyte (19). Native $\alpha_{2} M$ has a relatively long circulating half-life due to the inability to interact with $\alpha_{2} \mathbf{M}$ receptors (15). The clearance of $\alpha_{2} \mathbf{M}$-proteinase complex in the mouse is species independent; $\alpha$-macroglobulins from multiple species (including human and murine $\alpha_{2} M$ ) compete similarly for $\alpha_{2} \mathrm{M}$ receptors in vivo $(15,17)$.

The nature of the $\alpha_{2} \mathrm{M} / \mathrm{TGF}-\beta 1$ interaction has not been completely elucidated; however, TGF- $\beta 1$ binds preferentially to some forms of $\alpha_{2} \mathrm{M}$ that have undergone conformational change, such as $\alpha_{2} \mathrm{M}$-methylamine (11) and $\alpha_{2} \mathrm{M}$-plasmin (unpublished data). Since TGF- $\beta 1-\alpha_{2} M$ complexes do not interact with TGF- $\beta$ receptors $(10,11), \alpha_{2} M$ may serve as an "intercellular shuttle," mediating the clearance of TGF- $\beta 1$ from the circulation or directing the cytokine to specific cell types that express $\alpha_{2} M$ receptors (macrophages and hepatocytes). In this study, we have tested this hypothesis using the established in vivo mouse model system. Our results indicate that stable $\alpha_{2} \mathrm{M}$ - 
methylamine-TGF- $\beta 1$ complexes can be formed and that these complexes are cleared from the murine circulation by $\alpha_{2} \mathbf{M}$ receptors.

\section{Methods}

Proteins and reagents. Papain, p-nitrophenyl p'-guanidinobenzoate $\mathrm{HCl}$ (PNPGB), trypsin, and methylamine- $\mathrm{HCl}$ were purchased from Sigma Chemical Co., St. Louis, MO. The concentration of active enzyme in trypsin preparations was determined by the method of Chase and Shaw (20). Cis-dichlorodiammineplatinum (II) (cis-DDP) was purchased from Aldrich Chemical Co., Milwaukee, WI.

$\alpha_{2} \mathrm{M}$ was purified from human plasma by zinc chelate and gel filtration chromatography as described by Imber and Pizzo (16). $\alpha_{2} \mathrm{M}$-trypsin complex was prepared by reacting $\alpha_{2} M$ with a twofold molar excess of active trypsin. The bound trypsin was then inactivated with PNPGB. Highly purified ${ }^{125}$ I-TGF- $\beta 1(>97 \%)$ was purchased from R\&D Systems, Minneapolis, MN, or prepared by the method of Ruff and Rizzino (21). The sp act was between 30 and $100 \mu \mathrm{Ci} / \mu \mathrm{g}$. Equivalent results were obtained with both preparations of ${ }^{125}$ I-TGF- $\beta 1$.

Chemical modification of $\alpha_{2} M . \alpha_{2} M-$ methylamine was prepared by dialyzing purified $\alpha_{2} \mathrm{M}$ against $300 \mathrm{mM}$ methylamine, $50 \mathrm{mM}$ Tris$\mathrm{HCl}, \mathrm{pH} 8.2$, for $8 \mathrm{~h}$ at $25^{\circ} \mathrm{C}$. The preparation was then dialyzed exhaustively against $20 \mathrm{mM}$ sodium phosphate, $150 \mathrm{mM} \mathrm{NaCl}$, pH 7.4 (PBS). In a native gel electrophoresis system, $\alpha_{2} \mathrm{M}$-methylamine migrated in a single band with increased mobility compared with native (unreacted) $\alpha_{2} M$. This change in electrophoretic mobility confirmed that reaction was complete and that $\alpha_{2} \mathrm{M}$ conformational change occurred (22).

$\alpha_{2} \mathrm{M}$-methylamine was reacted with $1.67 \mathrm{mM}$ cis-DDP in PBS for 6 $\mathrm{h}$ at $37^{\circ} \mathrm{C}$ and then dialyzed against PBS at $4^{\circ} \mathrm{C}$. Under these conditions, the cis-DDP reacts with a critical methionine residue in the $\alpha_{2} \mathrm{M}$ receptor recognition site, forming a stable complex $\left(\alpha_{2} \mathrm{M}-\mathrm{M}_{\mathrm{Pt}}\right)$ that does not bind to $\alpha_{2} \mathrm{M}$ receptors (23). Each $\alpha_{2} \mathrm{M}-\mathrm{M}_{\mathrm{Pt}}$ preparation was screened using an in vitro rat hepatocyte binding assay as described elsewhere (24). $\alpha_{2} \mathrm{M}-\mathrm{M}_{\mathrm{Pt}}$ did not displace ${ }^{125} \mathrm{I}-\alpha_{2} \mathrm{M}$-methylamine from hepatocyte receptors at $4^{\circ} \mathrm{C}$.

$\alpha_{2} \mathrm{M}$-methylamine was treated with papain at $\mathrm{pH} 5.0$ as previously described (25). Papain digests $\alpha_{2} \mathrm{M}$-methylamine into one major fragment $(600 \mathrm{kD})$ and four equivalent $18-\mathrm{kD}$ peptides representing the $\mathrm{COOH}$ termini of the four $\alpha_{2} \mathrm{M}$ subunits (25). The $600-\mathrm{kD}$ fragment retains the basic structural features of $\alpha_{2} \mathrm{M}$-methylamine as shown by electron microscopy (24) but lacks the receptor binding domains (25). The $600-\mathrm{kD}$ fragment was purified by chromatography on Ultrogel AcA-22. In hepatocyte binding assays, $100 \mathrm{nM} 600-\mathrm{kD}$ fragment did not displace ${ }^{125} \mathrm{I}-\alpha_{2} \mathrm{M}$-methylamine $(1 \mathrm{nM})$ from receptors at $4^{\circ} \mathrm{C}$.

Formation of $\alpha_{2} M-T G F-\beta 1$ complexes. Radioiodinated TGF- $\beta 1$ was incubated with native $\alpha_{2} \mathrm{M}, \alpha_{2} \mathrm{M}$-methylamine, $\alpha_{2} \mathrm{M}-\mathrm{M}_{\mathrm{Pt}}$, or the $600-\mathrm{kD}$ fragment. The $\alpha_{2} \mathrm{M}$ and TGF- $\beta 1$ concentrations were $1.4 \mu \mathrm{M}$ and $1.2 \mathrm{nM}$, respectively. Incubations were conducted at $37^{\circ} \mathrm{C}$ for $2 \mathrm{~h}$ or the specified time. TGF- $\beta 1-\alpha_{2} \mathrm{M}$ complexes were separated from free TGF- $\beta 1$ by FPLC on prepacked Superose- 6 columns (Pharmacia LKB, Piscataway, NJ). The flow rate was $0.4 \mathrm{ml} / \mathrm{min}$. The extent of binding was determined by the radioactivity coeluting with the $\alpha_{2} \mathrm{M}$ in an early peak.

Electrophoresis and autoradiography. Radioiodinated TGF- $\beta 1$ (5.0 $\mathrm{nM}$ ) was incubated with the various forms of $\alpha_{2} \mathrm{M}(0.3 \mu \mathrm{M})$ for $1.5 \mathrm{~h}$ at $37^{\circ} \mathrm{C}$. PAGE was then performed on $5 \%$ slabs using the nondenaturing buffer system described by Van Leuven et al. (26). Binding of ${ }^{125}$ I-TGF$\beta 1$ to $\alpha_{2} M$ was determined by autoradiography. Free ${ }^{125}$ I-TGF- $\beta 1$ was not recovered in the gel.

Plasma clearance experiments. Plasma clearance studies were performed in 20-wk old CD-1 mice (Charles River Breeding Laboratories, Inc., Wilmington, MA) as previously described (18). Briefly, ${ }^{125}$ I-TGF$\beta 1$, ${ }^{125} \mathrm{I}-\alpha_{2} \mathrm{M}$, or various FPLC-purified ${ }^{125} \mathrm{I}-\mathrm{TGF}-\beta 1-\alpha_{2} \mathrm{M}$ complexes were injected into the lateral tail veins of anesthetized mice. The total injection volume was $400 \mu$ l. Blood samples $(25 \mu \mathrm{l})$ were taken, beginning at $10 \mathrm{~s}$, from the retroorbital venous plexus using heparinized hematocrit tubes. Radioactivity in each blood sample was determined in a gamma counter and plotted as a percentage of the radioactivity present in the 10-s sample. Each experiment was performed at least in triplicate.

Clearance competition experiments were performed by coinjecting FPLC-purified ${ }^{125} \mathrm{I}$-TGF- $\beta 1-\alpha_{2} \mathrm{M}$-methylamine and $1.0 \mathrm{mg}$ of $\alpha_{2} \mathrm{M}$ methylamine (40-fold molar excess over $\alpha_{2} \mathrm{M}$ present in FPLC preparation) or $0.5 \mathrm{mg}$ of $\alpha_{2} \mathrm{M}$-trypsin (20-fold molar excess over $\alpha_{2} \mathrm{M}$ present in FPLC preparation). $\alpha_{2} \mathrm{M}$-methylamine and $\alpha_{2} \mathrm{M}$-trypsin compete comparably for receptor binding sites in mice (15-18). Unlike $\alpha_{2} M$ methylamine, the TGF- $\beta 1$ binding activity of $\alpha_{2} \mathrm{M}$-trypsin is not increased compared with native $\alpha_{2} M(11)$.

Plasma clearance of a radioligand may result from reversible processes such as noncovalent binding to cell-surface receptors or irreversible processes such as endocytosis (15). To distinguish between these two possibilities, delayed competition experiments were performed. ${ }^{125} \mathrm{I}-\mathrm{TGF}-\beta 1-\alpha_{2} \mathrm{M}$-methylamine complex was injected intravenously in mice. After $15 \mathrm{~min}, 1.0 \mathrm{mg}$ of $\alpha_{2} \mathrm{M}$-methylamine was administered in a second intravenous injection. Blood sampling was conducted throughout. If the radioligand is reversibly bound to cellular receptors, the second injection causes redistribution of radioactivity back into the plasma (15). This result has been observed with asialotransferrin (27).

Organ distribution studies. ${ }^{125} \mathrm{I}$-TGF- $\beta 1$ or FPLC-purified ${ }^{125} \mathrm{I}$ TGF- $\beta 1-\alpha_{2} \mathrm{M}$-methylamine complex was injected intravenously in mice. After $45 \mathrm{~min}$, the animals were killed. The major body organs were recovered intact, rinsed in normal saline, blotted to remove surface moisture, and weighed. The radioactivity was then determined in each organ and expressed as a percentage of the total recovered radioactivity. The results were normalized for organ size by dividing the percentage of recovered radioactivity in each organ by the organ mass.

\section{Results}

$T G F-\beta 1$ binding to $\alpha_{2} M$. Superose-6 FPLC was used to study the binding of ${ }^{125} \mathrm{I}-\mathrm{TGF}-\beta 1$ to $\alpha_{2} \mathrm{M}$. In this chromatography system, recovery of free ${ }^{125} \mathrm{I}-\mathrm{TGF}-\beta 1$ was poor. Most of the radioactivity eluted as a broad peak after the total accessible volume of the column. It is important that no free ${ }^{125} \mathrm{I}-\mathrm{TGF}-\beta 1$ was recovered in the early elution volumes characteristic of $\alpha_{2} \mathrm{M}$.

${ }^{125} \mathrm{I}$-TGF- $\beta 1$ was incubated with $\alpha_{2} \mathrm{M}$-methylamine for 1.5 $h$ at $37^{\circ} \mathrm{C}$. When the preparation was subjected to chromatography on Superose- $6,50 \%$ of the radioactivity coeluted with the $\alpha_{2}$ M-methylamine, suggesting complex formation (Table I). The TGF- $\beta$ 1- $\alpha_{2}$ M-methylamine complex was separated from free TGF- $\beta 1$ by FPLC on Superose-6, stored at $4^{\circ} \mathrm{C}$ for $48 \mathrm{~h}$, and then subjected to FPLC again. Greater than $90 \%$ of the radioactivity was recovered and $98 \%$ of the recovered radioactivity eluted in the high molecular weight $\alpha_{2} \mathrm{M}$ peak. This result

Table I. Analysis of TGF- $\beta 1$ Binding to $\alpha_{2} M$ by Chromatography on Superose-6

\begin{tabular}{lccc}
\hline \multicolumn{1}{c}{$\alpha_{2} \mathrm{M}$ Species } & Temperature & Incubation time & $\begin{array}{c}\text { 125I-TGF- } \boldsymbol{\beta} \text { 1 } \\
\text { bound }\end{array}$ \\
\hline & ${ }^{\circ} \mathrm{C}$ & $h$ & $\%$ \\
Native & 22 & 1.0 & 3 \\
$\alpha_{2} \mathrm{M}$-methylamine & 22 & 1.0 & 35 \\
Native & 37 & 1.5 & 12 \\
$\alpha_{2} \mathrm{M}$-methylamine & 37 & 1.5 & 50 \\
$\alpha_{2} \mathrm{M}-\mathrm{M}_{\mathbf{P t}}$ & 37 & 1.5 & 50 \\
600-kD fragment & 37 & 1.5 & 33 \\
& & &
\end{tabular}


demonstrates that recovery of ${ }^{125}$ I-TGF- $\beta 1-\alpha_{2} M$-methylamine complex from Superose- 6 is nearly quantitative and that the purified complex is relatively stable.

The Superose- 6 chromatography system was used to compare the binding of ${ }^{125} \mathrm{I}$-TGF- $\beta 1$ to different forms of $\alpha_{2} \mathrm{M}$. Both native $\alpha_{2} \mathrm{M}$ and $\alpha_{2} \mathrm{M}$-methylamine bound TGF- $\beta 1$ without the aid of stabilizing cross-linking agents; however, the binding was much more extensive with $\alpha_{2} \mathrm{M}$-methylamine (Table I) confirming the work of other investigators (11).

To determine whether the TGF- $\beta 1$ binding site overlaps the $\alpha_{2} \mathrm{M}$ receptor binding site, ${ }^{125} \mathrm{I}-\mathrm{TGF}-\beta 1$ was incubated with $\alpha_{2} \mathrm{M}-\mathrm{M}_{\mathrm{Pt}}$ and the $600-\mathrm{kD}$ fragment. In $\alpha_{2} \mathrm{M}-\mathrm{M}_{\mathrm{Pt}}$, the receptor binding site is chemically modified (23). In the $600-\mathrm{kD}$ fragment, the receptor binding domain is enzymatically removed (25). Both preparations of modified $\alpha_{2} \mathrm{M}$-methylamine bound TGF- $\beta 1$ and the extent of binding was significantly greater than that observed with native $\alpha_{2} \mathbf{M}$.

Analysis of TGF- $\beta 1$ binding to $\alpha_{2} M$ by PAGE and autoradiography. To confirm the results of the chromatography experiments, binding of ${ }^{125} \mathrm{I}$-TGF- $\beta 1$ to the various $\alpha_{2} \mathrm{M}$ preparations was studied by PAGE and autoradiography (Fig. 1). As shown in the Coomassie blue-stained gel, $\alpha_{2} \mathrm{M}$-methylamine demonstrated increased mobility relative to native $\alpha_{2} M$. This change in electrophoretic migration is a well characterized consequence of $\alpha_{2} \mathrm{M}$ conformational change (14). The $600-\mathrm{kD}$ fragment and $\alpha_{2} \mathrm{M}-\mathrm{M}_{\mathrm{Pt}}$ also demonstrated increased mobility relative to native $\alpha_{2} \mathrm{M}$. A faint low mobility band present in lane $c$ may indicate that the $\alpha_{2} \mathrm{M}-\mathrm{M}_{\mathrm{Pt}}$ preparation included a small percentage of $\alpha_{2} \mathrm{M}$ dimers, consistent with the bifunctional nature of cis-DDP.

As demonstrated by autoradiography, each of the three modified $\alpha_{2} \mathrm{M}$ preparations bound significantly greater amounts of ${ }^{125}$ I-TGF- $\beta 1$ than native $\alpha_{2} \mathrm{M}$. These results are consistent with those obtained by chromatography. After incubation with native $\alpha_{2} \mathrm{M}$, most of the bound ${ }^{125} \mathrm{I}-\mathrm{TGF}-\beta 1 \mathrm{mi}-$ grated more rapidly than the major Coomassie blue-stained band. This result suggests that the TGF- $\beta 1$ may selectively bind to trace amounts of conformationally transformed $\alpha_{2} \mathrm{M}$ species in the native $\alpha_{2} \mathrm{M}$ preparation, even though these species are not detected by native or SDS-PAGE. Assuming a one:one stoichiometry for TGF- $\beta 1-\alpha_{2} \mathrm{M}$ complex, $<0.2 \%$ conformationally transformed species in the native $\alpha_{2} \mathrm{M}$ preparation might be sufficient to account for the TGF- $\beta 1$ binding observed in the PAGE and chromatography experiments.

Plasma clearance of $\alpha_{2} M$. The plasma clearance of human ${ }^{125} \mathrm{I}-\alpha_{2} \mathrm{M}$ has been reported previously (15-18). Equivalent studies are presented here in order to facilitate interpretation of the

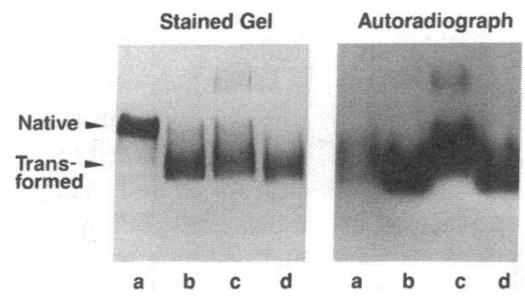

Figure 1. Binding of ${ }^{125} \mathrm{I}-\mathrm{TGF}-\beta 1$ to various forms of $\alpha_{2} M$ analyzed by PAGE and autoradiography. ${ }^{125} \mathrm{I}$ TGF- $\beta 1$ was incubated with native $\alpha_{2} \mathrm{M}$ (lane a), $\alpha_{2} \mathrm{M}$-methylamine (lane $b$ ), $\alpha_{2} \mathrm{M}-\mathrm{M}_{\mathrm{Pt}}$ (lane c), or the $600-\mathrm{kD}$

fragment (lane $d$ ). An equal amount of $\alpha_{2} \mathrm{M}$ was loaded in each lane. Electrophoresis was conducted for $0.5 \mathrm{~h}$ at $75 \mathrm{~V}$ followed by $3.5 \mathrm{~h}$ at $150 \mathrm{~V}$. The Coomassie stained gel and the autoradiograph have been aligned so that mobilities of the bands may be directly compared.

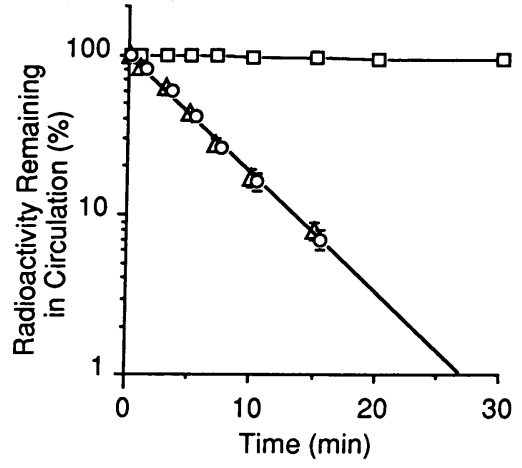

Figure 2. The plasma clearance of native ${ }^{125} \mathrm{I}$ $\alpha_{2} \mathrm{M}(\square),{ }^{125} \mathrm{I}-\alpha_{2} \mathrm{M}$ methylamine (o), and ${ }^{125} \mathrm{I}-\alpha_{2} \mathrm{M}$-trypsin ( $\Delta$ ). The error bars represent $1 \mathrm{SD}$.

${ }^{125} \mathrm{I}$-TGF- $\beta 1$ clearance experiments (Fig. 2). ${ }^{125} \mathrm{I}$-native $\alpha_{2} \mathrm{M}$ was injected intravenously. Blood sampling was performed for $30 \mathrm{~min}$. During this time, the circulating level of radioligand remained stable. By contrast, both ${ }^{125} \mathrm{I}-\alpha_{2} \mathrm{M}$-trypsin and ${ }^{125} \mathrm{I}-$ $\alpha_{2} \mathrm{M}$-methylamine cleared rapidly after intravenous injection. In both cases, elimination from the vascular compartment was described by a first-order process with a half-life of 3-5 min. The saturability of the $\alpha_{2} \mathrm{M}$-proteinase clearance pathway can be easily demonstrated in vivo (15). A large molar excess of $\alpha_{2} \mathrm{M}$-proteinase or $\alpha_{2} \mathrm{M}$-methylamine causes a concentrationdependent decrease in the clearance rate of ${ }^{125} \mathrm{I}-\alpha_{2} \mathrm{M}$-trypsin or ${ }^{125} \mathrm{I}-\alpha_{2} \mathrm{M}$-methylamine (15-18).

Plasma clearance of ${ }^{125} I-T G F-\beta 1$ and ${ }^{125} I-T G F-\beta 1-\alpha_{2} M-$ methylamine complex. The plasma clearance of ${ }^{125} \mathrm{I}-\mathrm{TGF}-\beta 1$ was complex (Fig. 3). More than $50 \%$ of the initial radioligand (that present at $10 \mathrm{~s}$ ) was eliminated within $2 \mathrm{~min}$. Subsequently, the rate of ${ }^{125}$ I-TGF- $\beta 1$ clearance decreased until a stable level of intravascular radioactivity was attained at 7-10 $\mathrm{min}$. The plasma clearance of TGF- $\beta 1$ in mice, reported here, is comparable to that determined in rats by Coffey et al. (28).

The plasma elimination of ${ }^{125} \mathrm{I}-\mathrm{TGF}-\beta 1-\alpha_{2}$ M-methylamine complex differed significantly from the clearance of the free growth factor. The clearance curve was monophasic and adequately described by a first-order process with a half-life of 4 min. By $30 \mathrm{~min}$, residual radioligand in the blood samples reached background levels $(<2 \%)$.

Organ distribution studies. The distribution of ${ }^{125} \mathrm{I}-\mathrm{TGF}-\beta 1$ was studied 45 min after intravenous injection (Table II). Radioactivity was recovered predominantly in the liver; however, significant levels were also detected in the kidneys and lungs. When the data were standardized for organ mass, the highest density of ${ }^{125} \mathrm{I}$-TGF- $\beta 1$ was present in the lungs.

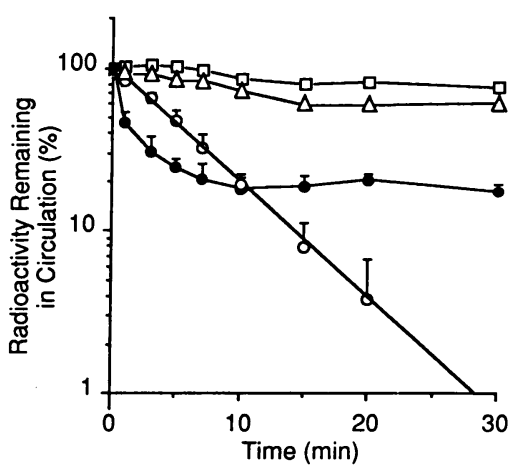

Figure 3. The plasma clearance of free ${ }^{125} \mathrm{I}$ TGF- $\beta 1(\bullet)$ and ${ }^{125} \mathrm{I}-$ TGF- $\beta 1$ bound to various forms of $\alpha_{2} M$ including $\alpha_{2} \mathrm{M}$ methylamine (o), $\alpha_{2} \mathrm{M}$ $M_{P_{t}}(\square)$, and the $600-\mathrm{kD}$ fragment $(\Delta)$. In each study, TGF- $\beta 1-\alpha_{2} M$ complex was resolved from free TGF- $\beta 1$ by chromatography on Superose-6. The error bars represent $1 \mathrm{SD}$. 
Table II. Organ Distribution Studies

\begin{tabular}{lccccc}
\hline & \multicolumn{2}{c}{ TGF- $\beta 1$} & & \multicolumn{2}{c}{ TGF- $\beta 1-\alpha_{2}$ M-methylamine } \\
\cline { 2 - 3 } \cline { 5 - 6 } Organ & $\begin{array}{c}\text { Radioactivity } \\
\text { recovered }\end{array}$ & $\begin{array}{c}\text { Normalized } \\
\text { radioactivity }\end{array}$ & & $\begin{array}{c}\text { Radioactivity } \\
\text { recovered }\end{array}$ & $\begin{array}{c}\text { Normalized } \\
\text { radioactivity }\end{array}$ \\
\cline { 6 - 7 } & $\%$ & $\% / g$ & & $\%$ & $\% / g$ \\
Liver & $65 \pm 6$ & $43 \pm 8$ & & $93 \pm 2$ & $58 \pm 9$ \\
Spleen & $4 \pm 1$ & $24 \pm 4$ & & $2 \pm 0$ & $17 \pm 4$ \\
Kidneys & $17 \pm 2$ & $43 \pm 5$ & & $3 \pm 0$ & $7 \pm 2$ \\
Lungs & $13 \pm 4$ & $72 \pm 5$ & & $2 \pm 1$ & $10 \pm 4$ \\
Heart & $1 \pm 1$ & $14 \pm 5$ & & $1 \pm 0$ & $3 \pm 1$ \\
\end{tabular}

Normalized radioactivities were determined by dividing the radioactivity recovered in each organ (percentage of total recovered radioactivity) by the organ mass (g). Values represent the mean \pm SEM ( $n=3$ for TGF- $\beta 1 ; n=4$ for $\alpha_{2}$ M-methylamine-TGF- $\beta 1$ ).

The organ distribution of ${ }^{125} \mathrm{I}-\mathrm{TGF}-\beta 1-\alpha_{2} \mathrm{M}$-methylamine complex was significantly different. Over $90 \%$ of the radioactivity was recovered in the liver. The nearly exclusive role of the liver was evident even after correcting the data for organ mass. The percentage of recovered radioactivity in each organ was within $2 \%$ of that reported for ${ }^{125} \mathrm{I}-\alpha_{2} \mathrm{M}$-methylamine elsewhere (15).

Plasma clearance of TGF- $\beta 1$ bound to modified forms of $\alpha_{2} M .{ }^{125} \mathrm{I}-\mathrm{TGF}-\beta 1-\alpha_{2} \mathrm{M}-\mathrm{M}_{\mathrm{Pt}}$ complex and the complex formed by ${ }^{125}$ I-TGF- $\beta 1$ with the $600-k D$ fragment did not clear from the circulation (Fig. 3). The plasma clearance profiles for these complexes were equivalent to those reported previously for ${ }^{125} \mathrm{I}-\alpha_{2} \mathrm{M}-\mathrm{M}_{\mathrm{Pt}}$ (23) and ${ }^{125} \mathrm{I}-600-\mathrm{kD}$ fragment (29). This result strongly suggests that an intact $\alpha_{2} \mathrm{M}$ receptor recognition site is necessary for the plasma clearance of TGF- $\beta 1-\alpha_{2} \mathrm{M}$-methylamine in mice.

Clearance competition experiments. FPLC-purified ${ }^{125} \mathrm{I}-$ TGF- $\beta 1-\alpha_{2} M$-methylamine was injected in the presence of excess $\alpha_{2} \mathrm{M}$-methylamine or $\alpha_{2} \mathrm{M}$-trypsin (Fig. 4 ). The competing ligands significantly decreased the rate of radioligand clearance. By contrast, a 40-fold molar excess of native $\alpha_{2} M$ had no effect (data not shown). These data indicate that ${ }^{125}$ I-TGF- $\beta 1-$ $\alpha_{2} \mathrm{M}$-methylamine clearance requires available $\alpha_{2} \mathrm{M}$ receptors in vivo. The TGF- $\beta 1$ binding activity of $\alpha_{2}$ M-trypsin is not

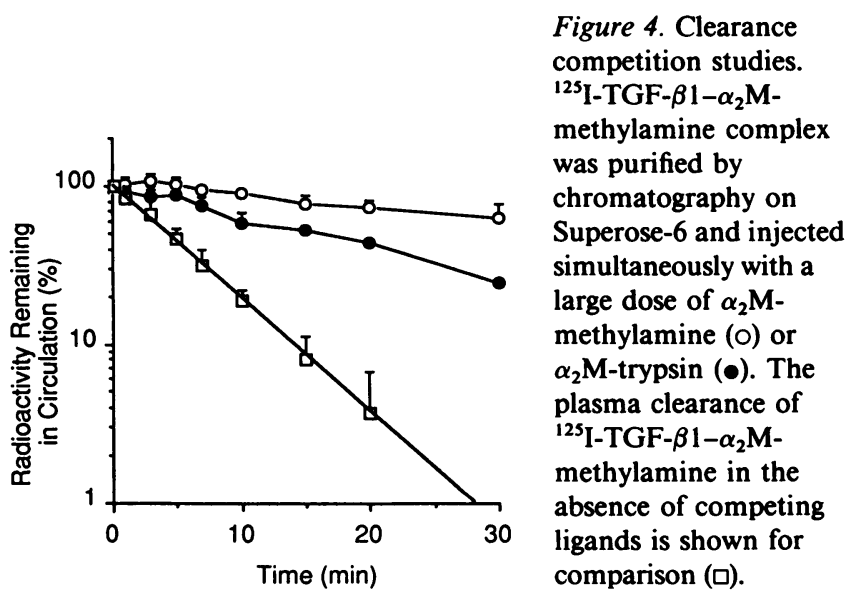

greater than that of native $\alpha_{2} \mathrm{M}$ (11). Therefore, the competing ligands did not affect the clearance of ${ }^{125} \mathrm{I}-\mathrm{TGF}-\beta 1-\alpha_{2} \mathrm{M}$-methylamine complex by interacting with the radioligand in vivo. Since $\alpha_{2} \mathbf{M}$-methylamine and $\alpha_{2} \mathbf{M}$-trypsin almost completely arrested ${ }^{125}$ I-TGF- $\beta 1-\alpha_{2}$ M-methylamine clearance, pathways for the plasma elimination of the radiolabeled complex other than the $\alpha_{2} M$ receptor probably do not exist in mice.

Delayed competition experiments were performed to determine if ${ }^{125}$ I-TGF- $\beta 1-\alpha_{2} M$-methylamine can be displaced back into the vascular compartment after clearance occurs (Fig. 5). The radioligand was injected alone and allowed to clear until $<20 \%$ remained. A large molar excess of unlabeled $\alpha_{2}$ M-methylamine was then injected. The competing ligand inhibited the clearance of the remaining ${ }^{125} \mathrm{I}-\mathrm{TGF}-\beta 1-\alpha_{2} \mathrm{M}$-methylamine; however, no significant increase in plasma radioactivity was observed. This study demonstrates that ${ }^{125} \mathrm{I}-\mathrm{TGF}-\beta 1-\alpha_{2} \mathrm{M}$ methylamine that clears from the circulation is not in reversible equilibrium with $\alpha_{2} \mathrm{M}$-methylamine in the plasma. While we cannot rule out irreversible (covalent) radioligand binding to cellular receptors, the results suggest that ${ }^{125} \mathrm{I}$-TGF- $\beta 1-\alpha_{2} \mathrm{M}$ methylamine undergoes endocytosis, as has been described for $\alpha_{2} \mathrm{M}$-methylamine after receptor binding in vivo (15).

In separate experiments, the plasma clearance of free ${ }^{125} \mathrm{I}$ TGF- $\beta 1$ was studied after injecting $\alpha_{2}$ M-trypsin $(0.5 \mathrm{mg})$ in order to block the $\alpha_{2} \mathrm{M}$ receptor-dependent clearance pathway. The clearance of the TGF- $\beta 1$ was not affected by the $\alpha_{2} \mathrm{M}$-trypsin (data not shown). This result suggests that the $\alpha_{2} \mathrm{M}$ receptor does not contribute to the plasma elimination of TGF- $\beta 1$ unless the TGF- $\beta 1$ is bound to a receptor-recognized form of $\alpha_{2} M$.

\section{Discussion}

The binding of TGF- $\beta 1$ to various forms of $\alpha_{2} M$ has been previously described $(10-12,30), \alpha_{2} \mathrm{M}$ is the most important carrier of TGF- $\beta 1$ in the circulation (10); however, the functional consequences of complex formation between TGF- $\beta 1$ and $\alpha_{2} \mathrm{M}$ remain unclear.

The studies presented in this investigation demonstrate that ${ }^{125}$ I-TGF- $\beta 1$ can be cleared from the circulation as a complex with $\alpha_{2} \mathrm{M}$-methylamine via the $\alpha_{2} \mathrm{M}$ receptor. The growth factor-carrier complex is sequestered almost exclusively in the liver, mirroring the organ distribution of ${ }^{125} \mathrm{I}-\alpha_{2} \mathrm{M}-$-methylamine or ${ }^{125} \mathrm{I}-\alpha_{2} \mathrm{M}$-proteinase. When the function of the $\alpha_{2} \mathrm{M}$ receptor was abrogated by altering the $\alpha_{2} \mathrm{M}$ receptor recognition site $\left(\alpha_{2} \mathrm{M}-\mathrm{M}_{\mathrm{Pt}}, 600-\mathrm{kD}\right.$ fragment $)$ or by coadministering a

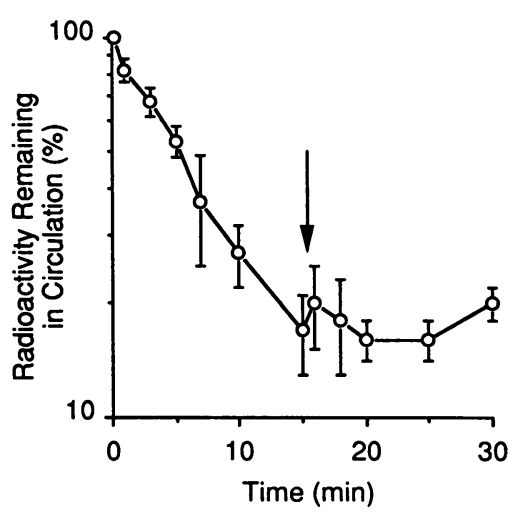

Figure 5. Delayed clearance competition studies. ${ }^{125}$ I-TGF- $\beta 1$ $\alpha_{2} \mathrm{M}$-methylamine complex was injected alone and allowed to clear for $15 \mathrm{~min}$. A large molar excess of $\alpha_{2} \mathrm{M}$ methylamine was then administered intravenously in a second injection. The time of the second injection is shown by the arrow. 
competing dose of receptor-recognized $\alpha_{2} \mathrm{M}\left(\alpha_{2} \mathrm{M}\right.$-methylamine, $\alpha_{2}$ M-trypsin), the complexed ${ }^{125}$ I-TGF- $\beta 1$ persisted in the circulation. These experiments suggest that $\alpha_{2} M$ and the $\alpha_{2} \mathrm{M}$ receptor may function as a system to limit the dispersal of TGF- $\beta 1$ released from platelets and stromal cells in vivo.

The available evidence indicates that active forms of TGF$\beta 1$ must be able to bind to specific TGF- $\beta$ receptors (2-6). In our plasma clearance studies, free TGF- $\beta 1$ was rapidly eliminated from the vascular compartment, most likely due to interaction with TGF- $\beta$ receptors located diffusely in multiple organs. By contrast, clearance of TGF- $\beta 1-\alpha_{2}$ M-methylamine complex was dependent on the $\alpha_{2} \mathrm{M}$ receptor exclusively. When interaction with the $\alpha_{2} \mathrm{M}$ receptor was prevented, alternate pathways for the plasma clearance of TGF- $\beta 1-\alpha_{2} M-$ methylamine were not available. The inability of TGF- $\beta$ receptors to recognize TGF- $\beta 1-\alpha_{2} M$ complex has been demonstrated previously in cell culture experiments $(10,11)$. This study confirms this result for the first time in an in vivo model system.

$\alpha_{2} \mathrm{M}$-methylamine provides a useful model to study the structure and function of $\alpha_{\mathbf{2}} \mathrm{M}$ after conformational change. Based on numerous physico-chemical studies (31), differences in the structure of $\alpha_{2} \mathrm{M}$-methylamine and $\alpha_{2} \mathrm{M}$-proteinase are minimal, perhaps no greater than the variability reported for different $\alpha_{2} \mathrm{M}$-proteinase complexes. From the standpoint of the current investigation, $\alpha_{2} M$-methylamine provides an excellent model to study $\alpha_{2} \mathrm{M}$ receptor interactions (15-18); however, this particular form of $\alpha_{2} M$ is not physiologically significant. Therefore, in order to hypothesize that the $\alpha_{2} \mathrm{M}$ receptor mediates TGF- $\beta 1$ clearance in vivo, one must identify an $\alpha_{2}$ M species that binds TGF- $\beta 1$ with high affinity and is $\alpha_{2} M$ receptor-recognized. Unpublished studies from our laboratories have identified a number of complexes that demonstrate these properties, including $\alpha_{2} \mathbf{M}$-plasmin. At this time, it is not clear why all $\alpha_{2} \mathrm{M}$-proteinase complexes do not uniformly demonstrate increased TGF- $\beta 1$ binding activity. Since plasmin activates the TGF- $\beta 1$ precursor molecule and reacts readily with $\alpha_{2} \mathbf{M}, \alpha_{2} \mathrm{M}$-plasmin complexes may play an important role in removing excess active growth factor from a site of TGF- $\beta 1$ precursor activation.

Native $\alpha_{2} \mathrm{M}$ in the plasma originates primarily from the liver (32); however, macrophages can also secrete $\alpha_{2} M$ at sites of inflammation or an immune response (33). Therefore, complexes of $\alpha_{2} \mathrm{M}$ with TGF- $\beta 1$ may form both inside and outside the vascular compartment. Since the hepatocyte is the primary cell responsible for clearing $\alpha_{2} \mathrm{M}$-methylamine and $\alpha_{2} \mathrm{M}$-proteinase from the circulation (19), it is likely that hepatocytes bind TGF- $\beta 1-\alpha_{2} \mathrm{M}$-methylamine complex as well. At this time, it is not clear whether TGF- $\beta 1$ retains any activity when presented to hepatocytes as a TGF- $\beta 1-\alpha_{2}$ M-methylamine complex by the $\alpha_{2} \mathrm{M}$ receptor.

Huang et al. (11) proposed that conformationally transformed $\alpha_{2} \mathbf{M}$ species (receptor recognized) may be responsible for most of the TGF- $\beta 1$ binding activity in the plasma. The studies presented here and elsewhere (30) support this hypothesis by demonstrating selective binding of ${ }^{125}$ I-TGF- $\beta 1$ to conformationally transformed $\alpha_{2} M$, even when the transformed $\alpha_{2} \mathbf{M}$ is present as a minor fraction in purified native $\alpha_{2} \mathbf{M}$ preparations. If the previously described latent form of TGF- $\beta 1(10$, 11 ) is TGF- $\beta 1-\alpha_{2}$ M-proteinase complex, then our studies suggest that the plasma half-life of this latent form is very short.

The selective binding of TGF- $\beta 1$ to conformationally transformed $\alpha_{2} \mathrm{M}$ does not necessarily mean that TGF- $\beta 1-\alpha_{2} \mathrm{M}$-pro- teinase complexes are more abundant than TGF- $\beta 1$-native $\alpha_{2} \mathrm{M}$ complex in the circulation. Plasma concentration is a function not only of complex formation but of plasma survival (plasma clearance). Due to the rapid clearance of TGF- $\beta 1-$ $\alpha_{2} M$-proteinase complex, the fraction of TGF- $\beta 1$ bound to native $\alpha_{2} \mathrm{M}$ in samples of plasma may be significantly higher than that predicted by in vitro binding studies.

In cell culture systems, TGF- $\beta 1$ is a long-acting inhibitor of hepatocyte proliferation under serum free conditions $(30,34$, $35)$. The mitoinhibitory activity of TGF- $\beta$ s towards hepatocytes in culture is decreased by serum or by purified $\alpha_{2} \mathbf{M}(30)$. In vivo, TGF- $\beta 1$ reversibly inhibits the proliferative response of hepatocytes following partial hepatectomy; however, the effect is transient and limited compared with the responses obtained in vitro (36). The role of $\alpha_{2} M$ and $\alpha_{2} M$ receptors in the in vivo response to TGF- $\beta 1$ is a topic for future studies.

Finally, it should be noted that TGF- $\beta 1$ is a single member of a family of growth factors that interact with $\alpha_{2} M$. Some factors such as IL- $1 \beta$ and TGF- $\beta 1$ bind preferentially to $\alpha_{2}$ Mproteinase complexes and $\alpha_{2} \mathrm{M}$-methylamine $(11,37)$ while others such as platelet-derived growth factor bind preferentially to the native form of the inhibitor (11). The studies presented here demonstrate for the first time clearance of a growth factor via a receptor system for a different protein. It is intriguing to speculate that the $\alpha_{2} \mathrm{M}$ receptor may provide a clearance pathway for other growth factors and cytokines as well.

\section{Acknowledgments}

This work was supported by the Pew Scholars Program in the Biomedical Sciences and by the Medical Research Council of Canada (MA 9611). J. LaMarre and G. K. Wollenberg are fellows of the Medical Research Council of Canada. S. W. Hall is a predoctoral fellow of the Medical Scientist Training Program (GM 07267). S. L. Gonias is the recipient of a Research Career Development Award (HL-02272).

\section{References}

1. Assosian, R. K., A. Komoriya, C. A. Meyers, D. M. Miller, and M. B. Sporn. 1983. Transforming growth factor- $\beta$ in human platelets. Identification of a major storage site, purification and characterization. J. Biol. Chem. 258:71557160 .

2. Sporn, M. B., A. B. Roberts, L. M. Wakefield, and B. de Crombrugghe. 1987. Some recent advances in the chemistry and biology of transforming growth factor- $\beta$. J. Cell Biol. 105:1039-1045.

3. Tucker, R. F., E. L. Branum, G. D. Shipley, R. J. Ryan, and H. L. Moses. 1984. Specific binding to cultured cells of ${ }^{125}$ I-labeled type $\beta$ transforming growth factor from human platelets. Proc. Natl. Acad. Sci. USA. 81:6757-6761.

4. Boyd, F. T., and J. Massague. 1989. Transforming growth factor- $\beta$ inhibition of epithelial cell proliferation linked to the expression of a 53-kD membrane receptor. J. Biol. Chem. 264:2272-2278.

5. Derynck, R., J. A. Jarrett, E. Y. Chen, D. H. Eaton, J. R. Bell, R. K. Assosian, A. B. Roberts, M. B. Sporn, and D. V. Goeddel. 1985. Human transforming growth factor- $\beta$ complementary DNA sequence and expression in normal and transformed cells. Nature (Lond.). 316:701-705.

6. Wakefield, L. M., D. M. Smith, K. C. Flanders, and M. B. Sporn. 1988. Latent transforming growth factor- $\beta$ from human platelets. A high molecular weight complex containing precursor sequences. J. Biol. Chem. 263:7646-7654.

7. Lyons, R. M., J. Keski-Oja, and H. L. Moses. 1988. Proteolytic activation of latent transforming growth factor- $\beta$ from fibroblast-conditioned medium. J. Cell Biol. 106:1659-1665.

8. Andres, J. L., K. Stanley, S. Cheifetz, and J. Massague. 1989. Membraneanchored and soluble forms of betaglycan, a polymorphic proteoglycan that binds transforming growth factor- $\beta$. J. Cell Biol. 109:3137-3145.

9. Mooradian, D. L., R. C. Lucas, J. A. Weatherbee, and L. T. Furcht. 1989. Transforming growth factor- $\beta 1$ binds to immobilized fibronectin. J. Cell Bio chem. 41:189-200.

10. O'Connor-McCourt, M. D., and L. M. Wakefield. 1987. Latent transforming growth factor- $\beta$ in serum. A specific complex with $\alpha_{2}$-macroglobulin. $J$. Biol. Chem. 262:14090-14099. 
11. Huang, S. S., P. O'Grady, and J. S. Huang. 1988. Human transforming growth factor $\beta-\alpha_{2}$-macroglobulin complex is a latent form of transforming growth factor $\beta$. J. Biol. Chem. 263:1535-1541.

12. McCaffrey, T. A., D. J. Falcone, C. F. Brayton, L. A. Agarwal, F. G. P. Welt, and B. B. Weksler. 1989. Transforming growth factor- $\beta$ activity is potentiated by heparin via dissociation of the transforming growth factor- $\beta / \alpha_{2}$-macroglobulin inactive complex. J. Cell Biol. 109:441-448.

13. Barrett, A. J., and P. N. Starkey. 1973. The interaction of $\alpha_{2}$-macroglobulin with proteinases. Biochem. J. 133:709-724.

14. Gonias, S. L., J. A. Reynolds, and S. V. Pizzo. 1982. Physical properties of $\alpha_{2}$-macroglobulin following reaction with methylamine and trypsin. Biochim. Biophys. Acta. 705:306-314.

15. Pizzo, S. V., and S. L. Gonias. 1984. Receptor-mediated protease regulation. In The Receptors. Vol. 1. P. M. Conn, editor. Academic Press, Inc., Orlando, FL. 178-221.

16. Imber, M. J., and S. V. Pizzo. 1981. Clearance and binding of two electrophoretic fast forms of $\alpha_{2}$-macroglobulin. J. Biol. Chem. 256:8134-8139.

17. Gonias, S. L., A. E. Balber, W. J. Hubbard, and S. V. Pizzo. 1983. Ligand binding, conformational change and plasma elimination of human, mouse and rat $\alpha$-macroglobulin protease inhibitors. Biochem. J. 209:99-105.

18. Gonias, S. L., and S. V. Pizzo. 1984. Chemical and structural modification of $\alpha_{2}$-macroglobulin: effects on receptor binding and endocytosis studied in an in vivo model. Ann. NY Acad. Sci. 421:457-471.

19. Davidsen, O., E. I. Christensen, and J. Gliemann. 1985. The plasma clearance of human $\alpha_{2}$-macroglobulin-trypsin complex in the rat is mainly accounted for by uptake into hepatocytes. Biochim. Biophys. Acta. 846:85-92.

20. Chase, T., and E. Shaw. 1967. p-Nitrophenyl-p'-guanidinobenzoate $\mathrm{HCl}$ : a new active site titrant for trypsin. Biochem. Biophys. Res. Commun. 29:508-514.

21. Ruff, E., and A. Rizzino. 1986. Preparation and binding of radioactively labeled porcine transforming growth factor type $\beta$. Biochem. Biophys. Res. Commun. 138:714-719.

22. Barrett, A. J., M. A. Brown, and C. A. Sayers. 1979. The electrophoretically "slow" and "fast" forms of the $\alpha_{2}$-macroglobulin molecule. Biochem. J. 181:401-418.

23. Pizzo, S. V., P. A. Roche, S. R. Feldman, and S. L. Gonias. 1986. Further characterization of the platinum reactive component of the $\alpha_{2}$-macroglobulin receptor recognition site. Biochem. J. 235:559-567.

24. Hussaini, I. M., N. L. Figler, and S. L. Gonias. 1990. The structure of $\alpha_{2}$-macroglobulin-methylamine after digestion with papain as determined by electron microscopy. Biochem. J. 270:291-295.

25. Sottrup-Jensen, L., J. Gliemann, and F. Van Leuven. 1986. Domain structure of human $\alpha_{2}$-macroglobulin. Characterization of a receptor binding domain obtained by digestion with papain. FEBS (Fed. Eur. Biochem. Soc.) Lett. 205:20-24.

26. Van Leuven, F., J.-J. Cassiman, and H. Van den Berghe. 1981. Functional modifications of $\alpha_{2}$-macroglobulin by primary amines. J. Biol. Chem. 256:90169022.

27. Ashwell, G., and A. G. Morell. 1974. The role of surface carbohydrates in the hepatic recognition and transport of circulating glycoproteins. Adv. Enzymol. Relat. Areas Mol. Biol. 41:99-129.

28. Coffey, R. J., Jr., L. J. Kost, R. M. Lyons, H. L. Moses, and N. F. LaRusso 1987. Hepatic processing of transforming growth factor $\beta$ in the rat. Uptake, metabolism, and biliary secretion. J. Clin. Invest. 80:750-757.

29. Roche, P. A., D. K. Strickland, J. J. Enghild, and S. V. Pizzo. 1988 Evidence that the platinum-reactive methionyl residue of the $\alpha_{2}$-macroglobulin receptor recognition site is not the carboxyl-terminal receptor binding domain. $J$. Biol. Chem. 263:6715-6721.

30. Lamarre, J., G. K. Wollenberg, J. Gaudle, and M. A. Hayes. 1990. $\alpha_{2}-$ Macroglobulin and serum preferentially counteract the mitoinhibitory effect of transforming growth factor- $\beta 2$ in rat hepatocytes. Lab. Invest. 62:545-551.

31. Sottrup-Jensen, L. 1987. $\alpha_{2}$-Macroglobulin and related thiol ester plasma proteins. In The Plasma Proteins. F. W. Putnam, editor. Academic Press, Orlando, FL. 192-291.

32. Munck-Petersen, C., B. S. Christiansen, L. Heickendorff, and J. Ingerslev. 1988. Synthesis and secretion of $\alpha_{2}$-macroglobulin by human hepatocytes in culture. Eur. J. Clin. Invest. 18:543-548.

33. Hovi, T., D. Mosher, and A. Vaheri. 1977. Cultured human monocytes synthesize and secrete $\alpha_{2}$-macroglobulin. J. Exp. Med. 145:1580-1589.

34. McMahon, J. B., W. L. Richards, A. A. del Campo, M. Song, and S. S. Thorgeiersson. 1986. Differential effects of transforming growth factor- $\beta$ on proliferation of normal and malignant rat liver epithelial cells in culture. Cancer Res. 46:4665-4671.

35. Wollenberg, G. K., E. Semple, B. A. Quinn, and M. A. Hayes. 1987. Inhibition of proliferation of normal, preneoplastic and neoplastic rat hepatocytes by TGF- $\beta$. Cancer Res. 47:6595-6599.

36. Russell, W. E., R. J. Coffey, A. J. Oullette, and H. L. Moses. 1988. Type $\beta$ transforming growth factor reversibly inhibits the early proliferative response to partial hepatectomy in the rat. Proc. Natl. Acad. Sci. USA. 85:5126-5130.

37. Borth, W. B., and T. A. Luger. 1989. Identification of $\alpha_{2}$-macroglobulin as a cytokine binding plasma protein. Binding of interleukin- $1 \beta$ to " $F$ " $\alpha_{2}$-macroglobulin. J. Biol. Chem. 264:5818-5825. 